\title{
Resveratrol down-regulates survivin and induces apoptosis in human multidrug-resistant SPC-A-1/CDDP cells
}

\author{
WEIGUO ZHAO ${ }^{1 *}$, PENGTAO BAO $^{1 *}$, HAOWEN $\mathrm{QI}^{2}$ and HOUCHENG YOU ${ }^{3}$ \\ ${ }^{1}$ Department of Respiratory Medicine, The Second Affiliated Hospital of Chinese PLA General Hospital, Beijing \\ 100091; ${ }^{2}$ Department of Respiratory Medicine, Xijing Hospital, Fourth Military Medical University, Xi'an 710032; \\ ${ }^{3}$ Department of Pharmacology, Affiliated Hospital of North Sichuan Medical College, Nanchong 637000, P.R. China
}

Received July 6, 2009; Accepted September 28, 2009

DOI: 10.3892/or_00000634

\begin{abstract}
We studied the effect of resveratrol treatment on multidrug-resistant human non-small cell lung cancer cells. Human multidrug-resistant SPC-A-1/CDDP cells were treated with resveratrol at a concentration of 25,50 , or $100 \mu \mathrm{M}$ in in vitro studies and nude mice were implanted with multidrug-resistant SPC-A-1/and fed a special diet that included resveratrol at a dose of either $1 \mathrm{~g} / \mathrm{kg} / \mathrm{day}$ or $3 \mathrm{~g} / \mathrm{kg} /$ day in in vivo studies. No adverse toxicological effects of resveratrol treatment were observed. The rate of cell proliferation, apoptosis ratio, cell cycle phase distribution, $\mathrm{IC}_{50}$ values of cisplatin, gefitinib, and paclitaxel, implanted tumour volume, and expression of survivin in resveratrol-treated and control mice were then determined. Resveratrol significantly inhibited the proliferation of SPC-A-1/CDDP cells, induced apoptosis, arrested the cell cycle phase between $\mathrm{G}_{0}-\mathrm{G}_{1}$ and $S$ phase or at the $\mathrm{G}_{2} / \mathrm{M}$ phase, decreased the $\mathrm{IC}_{50}$ values of multiple chemotherapeutic drugs, and showed anti-tumour effects in nude mice that had been implanted with SPC-A-1/ CDDP cells. In additional, resveratrol affected the proliferation of SPC-A-1/CDDP cells in a dose- and timedependent manner. Expression of survivin in SPC-A-1/CDDP cells decreased after they were treated with all concentrations of resveratrol and resveratrol was also found to have a dosedependent effect on survivin expression. Resveratrol can induce apoptosis in multidrug-resistant human NSCLC SPC-A-1/ CDDP cells by down-regulating the expression of survivin.
\end{abstract}

\section{Introduction}

Primary lung cancer is leading cause of cancer-related deaths worldwide and has a five-year overall survival rate of $<15 \%$.

Correspondence to: Dr Weiguo Zhao, Department of Respiratory Medicine, The Second Affiliated Hospital of Chinese PLA General Hospital, Beijing 100091, P.R. China

E-mail: zhaowg2008@qq.com

\section{${ }^{*}$ Contributed equally}

Key words: resveratrol, survivin, non-small cell lung cancer, Mutidrug-resistance
It is classified into two main histological groups: small cell lung cancer (SCLC) and the more common non-small cell lung cancer (NSCLC), which constitutes $~ 85 \%$ of all lung cancers (1). The poor prognosis of this malignancy may be partially based on the pronounced resistance to multiple chemotherapeutic drugs (multidrug resistance, or MDR) that is intrinsically present in most NSCLCs and is acquired during treatment in many SCLCs that are initially drugsensitive $(2,3)$. The intrinsic and acquired resistance of cancer cells to chemotherapeutic agents limits the efficacy of cancer treatment (4). MDR is defined as resistance to multiple structurally and functionally unrelated anticancer drugs that occurs after treatment with a single agent $(5,6)$. Multiple mechanisms contribute to chemoresistance and eventually lead to the failure of cancer chemotherapy (7). MDR has become a serious clinical problem, especially in patients with NSCLC, thus the treatment of NSCLC presents a significant clinical challenge $(8,9)$.

Resveratrol (3, 5, 4'-trihydroxy-stilbene) was first isolated from the roots of the white hellebore in 1940 and was later isolated from Polygonum cupsidatum, a medicinal plant $(10,11)$ (Fig. 1). From a botanical perspective, resveratrol acts as a phytoalexin, which is a toxic compound produced by plants in response to a parasitic attack or under conditions of stress (12). Starting in the 1980s, resveratrol began attracting special attention because of its diverse pharmacological properties, which included cancer chemoprevention and the prevention of cardiovascular and neurodegenerative diseases (13). Many studies have been published demonstrating the beneficial effects of resveratrol in cellular systems (14). Studies have confirmed that resveratrol has chemopreventative properties for many types of cancer, including breast, prostate, colon, and lung cancers (15). A more recent breakthrough is the discovery that resveratrol can increase the lifespan of yeast. Resveratrol is also able to activate apoptosis and to arrest the cell cycle (16). It has been shown that resveratrol does not have cytotoxic effects in animal models, however, low doses of resveratrol can sensitise cancer cells to low doses of cytotoxic drugs and may provide an innovative strategy to enhance the efficacy of anticancer therapy in various human cancers (17-19). Although resveratrol exerts diverse biological activities that affect both the progression and regression of lung cancers, the chemopreventive potential of this dietderived agent has not been well-studied in the treatment of 
multidrug-resistant cancers (20). Because of the biological properties described above, resveratrol appears to be a good candidate agent for chemopreventive or chemotherapeutic strategies and is believed to be a potential novel weapon in the treatment of multidrug-resistant NSCLC.

Cisplatin is an established anti-tumour agent that is used in the treatment of advanced human NSCLC. It is generally used to induce multidrug-resistant lung cancer cell lines in experimental studies to allow investigators to gain a deeper understanding of lung cancer (21). Although the development of resistance to cisplatin is one of the major obstacles faced in the successful treatment of NSCLC, the molecular mechanisms involved in the development of cisplatin resistance remain poorly understood (22). In order to overcome the problems related to drug resistance and to improve the clinical outcomes of patients with NSCLC, we sought to elucidate the effect that resveratrol has on the multidrugresistant human NSCLC cells with the ultimate goal of identifying a novel therapy for multidrug-resistant NSCLC.

\section{Materials and methods}

Cell culture. The multidrug-resistant human cell line SPC-A-1/ CDDP, which was generated at the Institute of Respiratory Disease of PLA (Xinqiao Hospital, Third Military Medical University, Chongqing, P.R. China), has stable cell biological characteristics and is a reliable model of multidrug-resistant NSCLC. The Institute of Respiratory Disease of PLA (Xinqiao Hospital, Third Military Medical University) provided us with human multidrug-resistant SPC-A-1/CDDP (non-small cell lung carcinoma) cells as a gift. Cells were grown in RPMI-1640 supplemented with $10 \%$ foetal bovine serum, penicillin $(100 \mathrm{U} / \mathrm{ml})$, and streptomycin $(100 \mathrm{U} / \mathrm{ml})$. The $\mathrm{pH}$ of the growth medium was adjusted from a pH of 7.2 to 7.4 by $\mathrm{Na}_{2} \mathrm{CO}_{3}$, and the cells were kept in a humidified incubator $37^{\circ} \mathrm{C}$ that was perfused with a gas mixture containing $1 \% \mathrm{O}_{2}$, $5 \% \mathrm{CO}_{2}$, and $95 \% \mathrm{~N}_{2}$. An additional three groups of cells were treated with differing concentrations $(25,50$, or $100 \mu \mathrm{mol} / \mathrm{l})$ of resveratrol (purity $>98 \%$, Sigma, USA) and stored in an incubator containing the same atmosphere.

Cell proliferation analysis. Cells were digested with $0.25 \%$ trypsin and $0.01 \%$ EDTA and then adjusted to be grown at a density of $1 \times 10^{4}$ cells $/ \mathrm{ml}$. Cells were cultured in DMEM medium supplemented with $10 \%$ foetal bovine serum (both from Gibco/Invitrogen, NY, USA) in a $37^{\circ} \mathrm{C}$ incubator with a humidified atmosphere containing $5 \% \mathrm{CO}_{2}$ and $95 \% \mathrm{O}_{2}$. After $24,48,72$, and $96 \mathrm{~h}$, the number of cells was determined by haemocytometer. Cell concentration was calculated as follows: cell concentration per millilitre $=$ total cell count in 4 squares $\mathrm{x} 2500 \mathrm{x}$ the dilution factor.

Cell cycle analysis. The cell cycle distribution of the cells in culture was analysed by flow cytometric analysis as previously described. Briefly, following incubation for 24,48 , or $72 \mathrm{~h}$, cells were digested with $0.25 \%$ trypsin (Sigma, St. Louis, $\mathrm{MO}$, USA), counted, centrifuged at $300 \mathrm{x}$ g for $5 \mathrm{~min}$, and fixed in ethanol at $4^{\circ} \mathrm{C}$ overnight. Then, the cells were washed and centrifuged. The resulting cell pellets were resuspended in an RNase solution $(0.02 \mathrm{mg} / \mathrm{ml}$; Sigma) containing

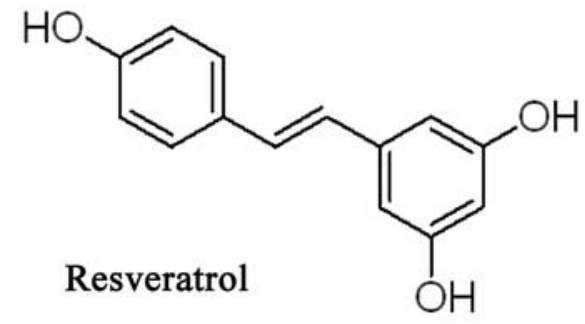

Figure 1. Chemical structure of resveratrol.

propidium iodide $\left(0.02 \mathrm{mg} / \mathrm{ml}\right.$; Sigma), and incubated at $4^{\circ} \mathrm{C}$ for $30 \mathrm{~min}$. The DNA content of approximately $1-2 \times 10^{5}$ stained cells were analysed using a FACScan flow cytometer equipped with the FACStation data management system running Cell Quest software (Becton Dickinson, San Jose, CA, USA). The results were expressed as a plot of fluorescence intensity versus cell number.

Annexin V/propidium iodide. To determine the number of apoptotic cells present in our samples, Annexin V assays were performed using an apoptosis detection kit (Annexin V-FITC/ PI staining kit; Immunotech Co., Marseille, France). Briefly, SPC-A-1/CDDP cells were seeded in 24-well plates and treated with resveratrol at differing concentrations for 24, 48 or $72 \mathrm{~h}$ in medium containing $1 \%$ FBS. Cells were harvested and resuspended in binding buffer $(10 \mathrm{mM}$ Hepes $/ \mathrm{NaOH}$, $\mathrm{pH} 7.4,140 \mathrm{mM} \mathrm{NaCl}$, and $2.5 \mathrm{mM} \mathrm{CaCl}_{2}$ ) at a concentration of $1 \times 10^{6}$ cells $/ \mathrm{ml}$. Next, $5 \mu 1$ of Annexin V-FITC (BD Pharmingen) and $10 \mu \mathrm{l}$ of PI (50 $\mu \mathrm{g} / \mathrm{ml})$ (Sigma) were added to $100 \mu 1$ of resuspended cells, which were then incubated for 15 min with fluorescein-conjugated annexin $\mathrm{V}$ and propidium iodide and analysed using the same flow cytometer and software used for the cell cycle analysis. PI-negative, annexin V-positive cells were considered to be 'early apoptotic' cells, while cells that were both PI and annexin V negative were considered normal cells.

MTT assay. The number of viable cells was determined by the 3-(4, 5-dimethylthiazol-2-yl)-2, 5-diphenyltetrazolium bromide (MTT) assay. Briefly, logarithmic phase SPC-A-1/ CDDP cells were cultured in 96-well plates (Greiner Bio-One $\mathrm{GmbH}$, Frickenhausen, Germany) at a density of $1 \times 10^{4}$ cells/ well. Cells were treated with cisplatin, gefitinib, or paclitaxel at the indicated concentrations. Each drug was applied to the SPC-A-1/CDDP cells at five different concentrations, each 5-fold larger than the next. After a $48 \mathrm{~h}$ incubation period, MTT (Sigma) dissolved in PBS was added to each well at a final concentration of $5 \mathrm{mg} / \mathrm{ml}$ and the cells were incubated at $37^{\circ} \mathrm{C}$ for $4 \mathrm{~h}$. The water-insoluble dark blue formazan crystals that formed during the cleavage of MTT in cells that were dissolved in DMSO. The optical density was then measured at a wavelength of $550 \mathrm{~nm}$ with a Bio-Rad 680 microplate reader (Bio-Rad, CA, USA). All experiments were performed in triplicate. The cell-growth inhibition potency of each chemotherapeutic agent is expressed as an $\mathrm{IC}_{50}$ value, which is defined as the concentration of a drug necessary to inhibit the growth of cells by $50 \%$. The $\mathrm{IC}_{50}$ of each drug was calculated using a logarithmic plot. The inhibitory rate was 
Table I. Effect of resveratrol on SPC-A-1/CDDP cells proliferation $\left(\mathrm{x} 10^{4}\right)$.

\begin{tabular}{lccccc}
\hline Treatment & $0 \mathrm{~h}$ & $24 \mathrm{~h}$ & $48 \mathrm{~h}$ & $72 \mathrm{~h}$ & $96 \mathrm{~h}$ \\
\hline Control & $1.03 \pm 0.11$ & $1.52 \pm 0.14$ & $2.78 \pm 0.23$ & $6.27 \pm 0.48$ & $10.17 \pm 0.72$ \\
Resveratrol $(25 \mu \mathrm{mol} / \mathrm{l})$ & $0.98 \pm 0.12$ & $1.46 \pm 0.16$ & $2.23 \pm 0.21^{\mathrm{a}}$ & $3.77 \pm 0.29^{\mathrm{a}, \mathrm{b}}$ & $5.69 \pm 0.61^{\mathrm{a}, \mathrm{b}}$ \\
Resveratrol $(50 \mu \mathrm{mol} / \mathrm{l})$ & $1.00 \pm 0.09$ & $1.42 \pm 0.10$ & $2.10 \pm 0.17^{\mathrm{a}}$ & $3.59 \pm 0.35^{\mathrm{a}, \mathrm{b}}$ & $5.47 \pm 0.49^{\mathrm{a}, \mathrm{b}}$ \\
Resveratrol $(100 \mu \mathrm{mol} / \mathrm{l})$ & $1.01 \pm 0.08$ & $1.39 \pm 0.13$ & $2.06 \pm 0.19^{\mathrm{a}}$ & $3.14 \pm 0.27^{\mathrm{a}}$ & $4.42 \pm 0.37^{\mathrm{a}}$ \\
\hline
\end{tabular}

Cell numbers of SPC-A-1/CDDP were calculated by hemacytometer at 24, 48, 72, or $96 \mathrm{~h}$ respectively after treated with resveratrol at 25,50 , or $100 \mu \mathrm{mol} / 1$. The values are shown as the mean $\pm \mathrm{SEM}$. ${ }^{\mathrm{a}} \mathrm{P}<0.05$, compared to the control group; ${ }^{\text {b }}<0.05$, compared to the group treated with $100 \mu \mathrm{mo} / \mathrm{l}$ resveratrol [least significant difference (LSD) test by ANOVA].

calculated as follows: inhibitory rate $=\left(1-\mathrm{OD}_{\mathrm{drug}} / \mathrm{OD}_{\text {control }}\right)$ $\mathrm{x} 100 \%$.

Mouse xenograft model of multi-drug resistant NSCLC. A solid tumour model was developed from cultured SPC-A-1/CDDP cells. Eighteen female BALB/C nude mice (18-22 g) were randomised to three groups and had a $1 \mathrm{ml}$ suspension of SPCA-1/CDDP cells ( $1 \times 10^{8} /$ each) injected at flank subcutaneously. The three groups were treated as follows: mice in Group $\mathrm{C}$ were free control, mice in Group T1 were treated with $1 \mathrm{~g} / \mathrm{kg}$ /day resveratrol, and mice in Group T2 were treated with $3 \mathrm{~g} / \mathrm{kg} /$ day resveratrol. The tumours were measured when the animals were sacrificed on day 28 and tumour volumes were calculated from caliper measurements using the following formula: $\mathrm{Vt}=$ [(LxW')/2] (L, longest diameter; W, shortest diameter) (23). Food and water were given ad libitum. All animal experimental procedures were approved by the Animal Care and Use Committee of Fourth Military Medical University.

Western blot analysis. Protein extracts of the SPC-A-1/ CDDP cells were prepared by lysing the cells in RIPA buffer (150 mM NaCl, $1 \%$ Nonidet P-40, 0.5\% sodium deoxycholate, $0.1 \%$ SDS, and $50 \mathrm{mM}$ Tris- $\mathrm{HCl} ; \mathrm{pH} 8$ ) along with $10 \mathrm{mM}$ EDTA, $1 \mathrm{mM}$ sodium orthovanadate and $1 \mathrm{mM}$ phenylmethylsulfonylfluoride (PMSF; all from Sigma) for $30 \mathrm{~min}$ at $4^{\circ} \mathrm{C}$. Samples were then centrifuged at $14,000 \mathrm{x}$ g for $25 \mathrm{~min}$ at $4^{\circ} \mathrm{C}$. The protein concentration in the supernatant was determined using the BCA protein assay kit (HyClone-Pierce, UT, USA). Equivalent amounts (60 $\mu \mathrm{g}$ protein/lane) of protein lysates were electrophoretically separated on a $12 \%$ SDS-polyacrylamide gel and transferred onto a nitrocellulose membrane (0.22 $\mu \mathrm{m}$, Invitrogen) in a transfer tank (Bio-Rad) using the submerged method. The membrane was blocked for $2 \mathrm{~h}$ at room temperature in PBS containing 0.1\% Tween-20 (Sigma) and 5\% non-fat dried milk (Carnation, USA), and then incubated with the primary antibody in dilution buffer ( $1 \mathrm{X}$ TBS, $0.1 \%$ Tween-20 with $5 \%$ BSA) with gentle agitation overnight at $4{ }^{\circ} \mathrm{C}$. The primary antibodies we used were antisurvivin and anti-caspase 3 (diluted 1:400, 1:200, Santa Cruz, CA, USA, respectively), and anti-ß-actin (diluted 1:400, Santa Cruz). Then, the membranes were washed in dilution buffer (1X TBS, $0.1 \%$ Tween-20 with 5\% BSA) and incubated for $1 \mathrm{~h}$ with horseradish-peroxidase-conjugated (HRPconjugated) secondary antibodies, and finally developed using an ECL system (Cell Signaling Technology, Beverly, MA, USA). The secondary antibodies we used were HRPconjugated anti-rabbit IgG (diluted 1:2000) and HRPconjugated anti-mouse IgG (diluted 1:2000, both from Cell Signaling Technology). The Western blots were performed following Laemmli's method and the greyscale values of each band on the blots were measured using BandScan 4.3.

Statistical analysis. All statistical analyses were carried out using SPSS 14.0 statistical software. Data are expressed as the mean \pm the standard error of mean (SEM) of separate experiments. Pathological classifications were analysed by the Friedman test and the Q-test. Differences in measured parameters between the groups were analysed using one-factor ANOVA and Fisher's least significant difference test. $\mathrm{P} \leq 0.05$ was considered statistically significant.

\section{Results}

Effect of resveratrol on SPC-A-1/CDDP cell proliferation. The number of viable SPC-A-1/CDDP cells was counted using a haemocytometer after they were incubated with resveratrol for 24, 48, 72, and $96 \mathrm{~h}$ (Table I). Compared to untreated samples, those treated with resveratrol had fewer viable cells present, indicating that resveratrol significantly inhibited SPC-A-1/CDDP cell proliferation. Table I shows the number of viable SPC-A-1/CDDP cells present at the indicated time points in the control group and in the groups treated with 25,50 , or $100 \mu \mathrm{mol} / 1$ resveratrol. Resveratrol inhibited SPC-A-1/CDDP cell proliferation in a dose- and timedependent manner. Cell proliferation did not differ significantly between the control group and the resveratroltreated groups at $24 \mathrm{~h}$. However, resveratrol was found to inhibit cell proliferation at $48 \mathrm{~h}(\mathrm{P}<0.05)$, although there were no significant differences observed between the different concentrations of resveratrol used $(\mathrm{P}>0.05)$. At 72 and $96 \mathrm{~h}$, there were also found to be fewer viable cells in the resveratrol-treated groups and resveratrol was found to inhibit cell proliferation in a dose-dependent manner: cells treated $100 \mu \mathrm{mol} / 1$ resveratrol exhibited significantly growth inhibition compared with cells treated with 25 and $50 \mu \mathrm{mol} / \mathrm{l}$ resveratrol $(\mathrm{P}<0.05)$. No significant differences were observed between cells treated with $25 \mu \mathrm{mol} / 1$ resveratrol as compared to cells treated with $50 \mu \mathrm{mol} / 1$ resveratrol $(\mathrm{P}>0.05)$. 
Table II. Effects of resveratrol on the 50\% inhibitory concentration of cisplatin, gefitinib, and paclitaxel $(\mu \mathrm{g} / \mathrm{ml})$.

\begin{tabular}{llll}
\hline Treatment & \multicolumn{1}{c}{ Cisplatin } & \multicolumn{1}{c}{ Gefitinib } & \multicolumn{1}{c}{ Paclitaxel } \\
\hline Control & $0.6824 \pm 0.057$ & $0.5713 \pm 0.043$ & $0.3812 \pm 0.021$ \\
Resveratrol $(25 \mu \mathrm{mol} / \mathrm{l})$ & $0.4617 \pm 0.035^{\mathrm{a}, \mathrm{b}}$ & $0.3269 \pm 0.045^{\mathrm{a}, \mathrm{b}}$ & $0.2358 \pm 0.025^{\mathrm{a}, \mathrm{b}}$ \\
Resveratrol $(50 \mu \mathrm{mol} / \mathrm{l})$ & $0.4369 \pm 0.041^{\mathrm{a}, \mathrm{b}}$ & $0.2984 \pm 0.034^{\mathrm{a}, \mathrm{b}}$ & $0.2157 \pm 0.018^{\mathrm{a}, \mathrm{b}}$ \\
Resveratrol $(100 \mu \mathrm{mol} / \mathrm{l})$ & $0.2975 \pm 0.033^{\mathrm{a}}$ & $0.0871 \pm 0.011^{\mathrm{a}}$ & $0.0949 \pm 0.012^{\mathrm{a}}$ \\
\hline
\end{tabular}

Effect of cisplatin, gefitinib, and paclitaxel on $\mathrm{IC}_{50}$ of SPC-A-1/CDDP cells were deteced by MTT assay respectively after treated with resveratrol at 25,50 , or $100 \mu \mathrm{mol} / 1$. The values are shown as the mean $\pm \mathrm{SEM}$. ${ }^{\mathrm{a}} \mathrm{P}<0.05$, compared to the control group; ${ }^{\mathrm{P}}<0.05$, compared to the group treated with $100 \mu \mathrm{mol} / 1$ resveratrol [least significant difference (LSD) test by ANOVA].

Table III. Effect of resveratrol on SPC-A-1/CDDP cells cycle distribution (\%).

\begin{tabular}{lccc}
\hline Treatment & $\mathrm{G}_{0}-\mathrm{G}_{1}(\%)$ & $\mathrm{S}(\%)$ & $\mathrm{G}_{2}-\mathrm{M}(\%)$ \\
\hline Control & $58.22 \pm 3.12$ & $28.92 \pm 2.83$ & $12.86 \pm 1.13$ \\
$\begin{array}{l}\text { Resveratrol } \\
(25 \mu \mathrm{mol} / \mathrm{l})\end{array}$ & $68.77 \pm 8.54^{\mathrm{a}, \mathrm{b}}$ & $21.92 \pm 2.27^{\mathrm{a}, \mathrm{b}}$ & $9.31 \pm 1.01^{\mathrm{a}, \mathrm{b}}$ \\
$\begin{array}{l}\text { Resveratrol } \\
(50 \mu \mathrm{mol} / \mathrm{l})\end{array}$ & $71.13 \pm 7.53^{\mathrm{a}, \mathrm{b}}$ & $20.38 \pm 2.39^{\mathrm{a}, \mathrm{b}}$ & $8.49 \pm 0.92^{\mathrm{a}, \mathrm{b}}$ \\
$\begin{array}{l}\text { Resveratrol } \\
(100 \mu \mathrm{mol} / \mathrm{l})\end{array}$ & $81.17 \pm 8.22^{\mathrm{a}}$ & $12.35 \pm 1.37^{\mathrm{a}}$ & $6.48 \pm 0.74^{\mathrm{a}}$ \\
\hline
\end{tabular}

SPC-A-1/CDDP cells were treated resveratrol with at various concentrations $(25,50$, or $100 \mu \mathrm{mol} / \mathrm{l})$ for $48 \mathrm{~h}$. Resveratrol caused an accumulation of cells in the $\mathrm{G}_{0}-\mathrm{G}_{1}$ phases and diminished cells in the $\mathrm{S}$ and $\mathrm{G}_{2}-\mathrm{M}$ phases compared with control untreated cells. Data are presented as mean $\pm \mathrm{SE}$. ${ }^{\mathrm{a}} \mathrm{P}<0.05$, compared to the control group; ${ }^{b} \mathrm{P}<0.05$, compared to the group treated with $100 \mu \mathrm{mol} / 1$ resveratrol [least significant difference (LSD) test by ANOVA].

Effects of resveratrol on the $I C_{50}$ of cisplatin, gefitinib, and paclitaxel. The effects of resveratrol on the $\mathrm{IC}_{50}$ of cisplatin, gefitinib, and paclitaxel in SPC-A-1/CDDP cells were assessed by the MTT assay. Table II shows the $\mathrm{IC}_{50}$ values for cisplatin, gefitinib, and paclitaxel in untreated SPC-A-1/CDDP as well as cells treated with resveratrol. The $\mathrm{IC}_{50}$ of each drug was significantly lower for cells treated with resveratrol as compared to untreated cells $(\mathrm{P}<0.05)$. Additionally, resveratrol had a dose-dependent influence on the $\mathrm{IC}_{50}$ of each drug. Cells treated with $100 \mu \mathrm{mol} / 1$ resveratrol had significantly lower $\mathrm{IC}_{50}$ values for each drug as compared to cells treated with 25 or $50 \mu \mathrm{mol} / 1$ resveratrol $(\mathrm{P}<0.05)$. There was no significant difference observed between the $\mathrm{IC}_{50}$ values of cells treated with $25 \mu \mathrm{mol} / 1$ resveratrol as compared to cells treated with $50 \mu \mathrm{mol} / 1$ resveratrol $(\mathrm{P}>0.05)$.

Effects of resveratrol on the cell cycle distribution of SPC-A-1/ $C D D P$ cells. The cellular DNA content of resveratrol-treated cells and untreated cells was analysed by flow cytometry to
Table IV. Effect of resveratrol on apoptosis of SPC-A-1/ CDDP cells (\%).

\begin{tabular}{lccc}
\hline Treatment & $24 \mathrm{~h}$ & $48 \mathrm{~h}$ & $72 \mathrm{~h}$ \\
\hline Control & $1.6 \pm 0.21$ & $3.4 \pm 0.48$ & $6.5 \pm 0.71$ \\
Resveratrol & $5.9 \pm 0.68^{\mathrm{a}, \mathrm{b}}$ & $15.9 \pm 1.87^{\mathrm{a}, \mathrm{b}}$ & $21.9 \pm 2.84^{\mathrm{a}, \mathrm{b}}$ \\
$(25 \mu \mathrm{mol} / \mathrm{l})$ & & & \\
$\begin{array}{l}\text { Resveratrol } \\
(50 \mu \mathrm{mol} / \mathrm{l})\end{array}$ & $6.6 \pm 0.71^{\mathrm{a}, \mathrm{b}}$ & $17.7 \pm 2.14^{\mathrm{a}, \mathrm{b}}$ & $24.5 \pm 3.27^{\mathrm{a}, \mathrm{b}}$ \\
Resveratrol & $7.7 \pm 0.83^{\mathrm{a}}$ & $26.9 \pm 3.24^{\mathrm{a}}$ & $42.8 \pm 5.63^{\mathrm{a}}$ \\
$(100 \mu \mathrm{mol} / \mathrm{l})$ & & & \\
\hline
\end{tabular}

SPC-A-1/CDDP cells were treated resveratrol with at various concentrations $(25,50$, or $100 \mu \mathrm{mol} / \mathrm{l})$ for 24,48 or $72 \mathrm{~h}$. Resveratrol caused an increasing of apoptosis compared with control untreated cells. Data are presented as mean $\pm \mathrm{SE}$. ${ }^{\mathrm{a} P}<0.05$, compared to the control group; ${ }^{b} \mathrm{P}<0.05$, compared to the group treated with $100 \mu \mathrm{mol} / 1$ resveratrol [least significant difference (LSD) test by ANOVA].

detect changes in the cell cycle distribution of the SPC-A-1/ CDDP cells. DNA histogram analyses showed that resveratrol induced changes in the cell cycle profile of treated cells (Table III). Specifically, resveratrol triggered a significant increase in the number of cells in $\mathrm{G}_{0}-\mathrm{G}_{1}$ phase and a corresponding decrease in the number of cells in $\mathrm{S}$ and $\mathrm{G}_{2}-\mathrm{M}$ phase. Similar to the findings of the $\mathrm{IC}_{50}$ analysis, resveratrol induced changes in the cell cycle distribution of SPC-A-1/ CDDP cells in a dose-dependent manner. Treatment with $100 \mu \mathrm{mol} / 1$ resveratrol was found to induce a significantly larger change in the distribution of cells in the cell cycle as compared treatment with 25 or $50 \mu \mathrm{mol} / 1$ resveratrol $(\mathrm{P}<0.05)$. There were no significant differences in cell cycle distribution noted between cells treated with $25 \mu \mathrm{mol} / 1$ resveratrol as compared to cells treated with $50 \mu \mathrm{mol} / \mathrm{l}$ resveratrol ( $\mathrm{P}>0.05)$.

Effects of resveratrol on induction of apoptosis in SPC-A-1/ $C D D P$ cells. To quantify the early apoptotic effects resveratrol had on SPC-A-1/CDDP cells, the cells were stained with annexin $\mathrm{V}$ and propidium iodide (PI) following resveratrol exposure. Apoptosis of SPC-A-1/CDDP cells occurred after 
A
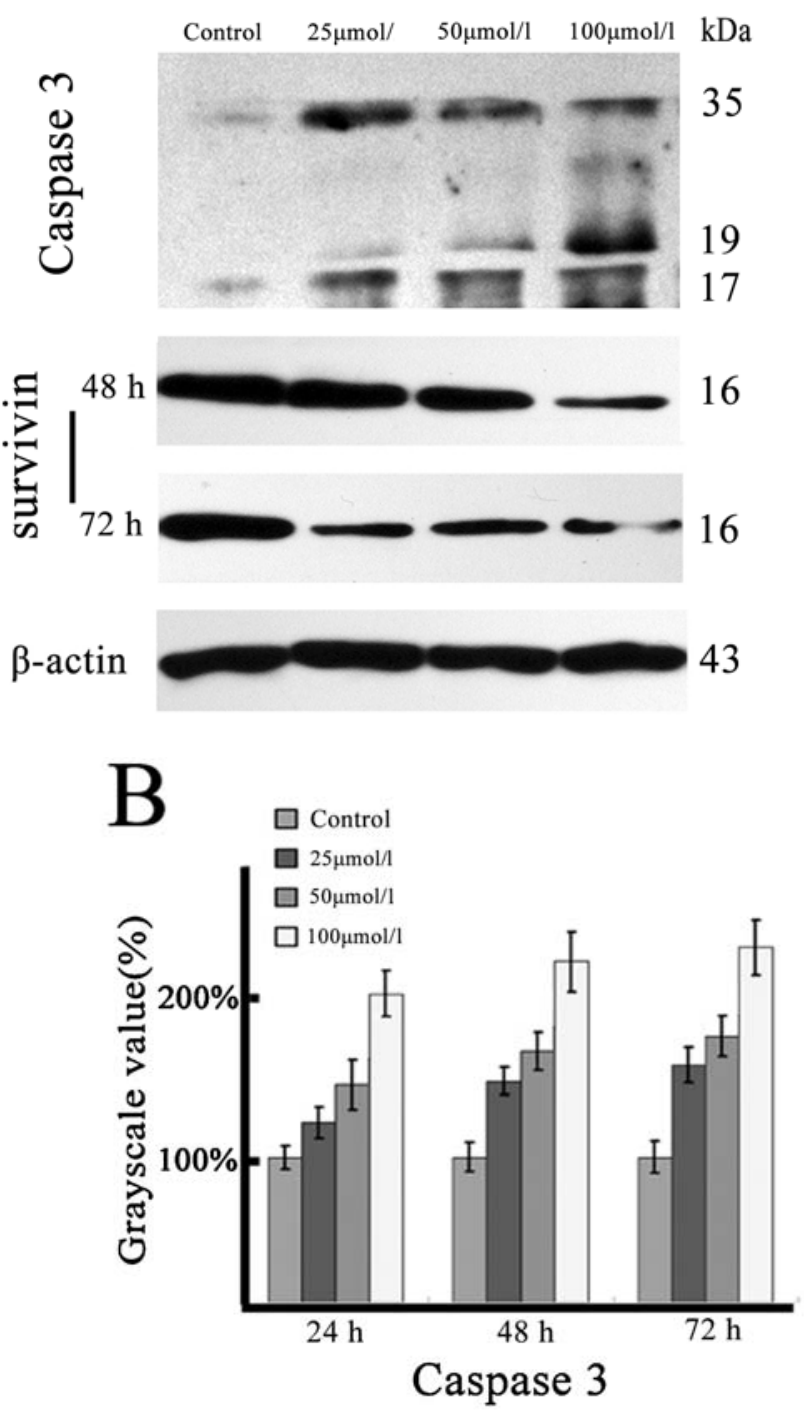

resveratrol treatment, and the number of apoptotic cells increased in a time- and dose-dependent manner, with all resveratrol concentrations $(25,50$, or $100 \mu \mathrm{mol} / \mathrm{l})$ inducing apoptosis at all time points $(24,48$, and $72 \mathrm{~h}$ ) (Table IV).

To investigate the contribution of the extrinsic apoptotic pathway in resveratrol-induced apoptosis, we assessed the activation of caspase- 3 , and caspase- 3 was found to be activated in cells undergoing resveratrol-induced apoptosis. Fig. 2A shows that in SPC-A-1/CDDP cells treated with resveratrol (at all concentrations), caspase-3 was rapidly and substantially cleaved. Additionally, greatly increased caspase- 3 activation was observed $72 \mathrm{~h}$ after treatment with $100 \mu \mathrm{mol} / \mathrm{l}$ resveratrol as compared to treatment with $25 \mu \mathrm{mol} / \mathrm{l}$ or $50 \mu \mathrm{mol} / \mathrm{l}(234 \pm 26.7 \%$ versus $197 \pm 20.4 \%$ and $189 \pm 16.3 \%$, respectively; $\mathrm{P}<0.05)$. Thus, our data suggested that the extrinsic apoptotic pathway (mediated by caspase-3) was activated in resveratrol induced apoptosis and that resveratrol had a dose- and time-dependent effect on the expression of caspase-3.

Survivin expression in SPC-A-1/CDDP cells treated with resveratrol. To determine the involvement of survivin in resveratrol-induced apoptosis of SPC-A-1/CDDP cells, the
Figure 2. Survivin and caspase-3 activation in the resveratrol-induced apoptosis of SPC-A-1/CDDP cells: (A) expression of survivin SPC-A-1/ CDDP cells treated with different concentrations of resveratrol at $48 \mathrm{~h}$ and $72 \mathrm{~h}$; expression of caspase- 3 at $48 \mathrm{~h}$. Resveratrol had dose- and timedependent effects on survivin and caspase-3 expression in SPC-A-1/CDDP cells. (B) Statistical analysis of the Western blots.

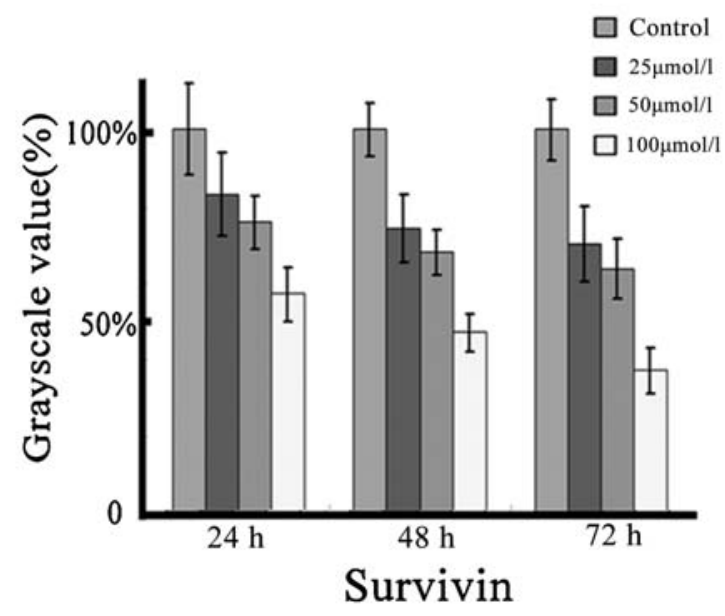

steady-state levels of survivin were measured by Western blot analysis (Fig. 2A). Survivin expression decreased significantly after treatment in all cell samples treated with resveratrol (at concentrations of 25,50 or $100 \mu \mathrm{mol} / \mathrm{l}$ ) 24,48 , and $72 \mathrm{~h}$ after treatment as compared to the control group. Additionally, resveratrol inhibited survivin expression in a dose-dependent manner. Treatment of SPC-A-1/CDDP cells with $100 \mu \mathrm{mol} / 1$ resveratrol decreased survivin expression significantly more than treatment with $25 \mu \mathrm{mol} / 1$ or $50 \mu \mathrm{mol} / 1$ resveratrol $(\mathrm{P}<0.05)$. For example, the ratio of survivin expression in resveratrol-treated cells as compared to controls was $74.0 \pm 9.2 \%, 67.8 \pm 6.1 \%$, and $46.9 \pm 5.8 \%$ in cells treated with 25,50 or $100 \mu \mathrm{mo} / 1$ resveratrol, respectively, at $48 \mathrm{~h}$.

Western blot analysis revealed that survivin levels were decreased in SPC-A-1/CDDP cells undergoing resveratrolinduced apoptosis, indicating that inhibition of surviving expression is the mechanism underlying resveratrol-induced apoptosis

Anti-tumour effects of resveratrol in nude mice. Having shown the anti-proliferative activity of resveratrol in vitro, we went on to evaluate the anti-tumour properties of resveratrol 
Table V. Anti-tumor effect of resveratrol on SPC-A-1/CDDP cells in nude mice.

\begin{tabular}{lll}
\hline Treatment & Tumour size $\left(\mathrm{mm}^{3}\right)$ & Tumour weight $(\mathrm{g})$ \\
\hline Control & $895.67 \pm 157.23$ & $0.72 \pm 0.17$ \\
$1 \mathrm{~g} / \mathrm{kg} /$ day & $527.5 \pm 75.7^{\mathrm{a}, \mathrm{b}}$ & $0.41 \pm 0.13^{\mathrm{a}, \mathrm{b}}$ \\
$3 \mathrm{~g} / \mathrm{kg} /$ day & $287.9 \pm 81.2^{\mathrm{a}}$ & $0.23 \pm 0.04^{\mathrm{a}}$ \\
\hline
\end{tabular}

Nude mice with SPC-A-1/CDDP transplant tumor were treated with (orally) resveratrol $1 \mathrm{~g} / \mathrm{kg}$ or $3 \mathrm{~g} / \mathrm{kg}$ every day for 28 days. Data are presented as mean $\pm \mathrm{SE}$. ${ }^{\mathrm{a}}<0.05$, compared to the control group; ${ }^{\mathrm{b}} \mathrm{P}<0.05$, compared to the group treated with $3 \mathrm{~g} / \mathrm{kg} /$ day resveratrol [least significant difference (LSD) test by ANOVA].

in nude mice that had been implanted with SPC-A-1/CDDP cells. Compared to the control group, the group treated with resveratrol (either $1 \mathrm{~g} / \mathrm{kg} /$ day or $3 \mathrm{~g} / \mathrm{kg}$ /day) demonstrated significantly inhibited tumour growth, both in terms of tumour size and weight (Table V and Fig. 3). Additionally, resveratrol was found to inhibit the tumour growth in a dose-dependent manner $(\mathrm{P}<0.05)$. No adverse effects of resveratrol were observed in treated mice.

\section{Discussion}

Multidrug resistance is the major cause of chemotherapy failure in non-small cell lung cancer patients (24). The causes of MDR-induced chemotherapy failure are complex and may be determined by multiple tumour characteristics, such as the proportion of tumour cells that are not actively dividing, the adequacy of the tumour's blood supply, as well as the multidrug resistance phenotype (25). Several mechanisms are responsible for the development of MDR, including the overexpression of transmembrane transporter molecules, specifically resistance P-glycoprotein (Pgp) and multidrug resistance-associated protein (MRP), which have been defined as cellular drug targets of chemotherapeutic agents (26). However, several MDR cell lines have been described that do not overexpress either Pgp or MRP, indicating that alternative mechanisms of MDR must be occurring (27). In lung cancer, the role that the different forms of multidrug resistance play is complex and only partially understood. Therefore, it is critical to identify proteins or genes that can be used to predict chemotherapy success and that can be used in the development of chemoprevention strategies for multidrug-resistant NSCLC $(28,29)$.

It has been revealed that resveratrol has the ability to suppress growth of many chemically induced and spontaneously occurring tumours. Furthermore, resveratrol has been shown to inhibit the local growth and dissemination of several transplantable tumours in laboratory animals (30). Due to its valuable biological properties and lack of significant side effects even after long-term administration, it seems that resveratrol is one of the most promising agents that could be applied in the future in cancer prevention strategies and cancer therapy in humans (31).

In this study, we examined the effect of resveratrol on multidrug-resistant human NSCLC cells (SPC-A-1/CDDP

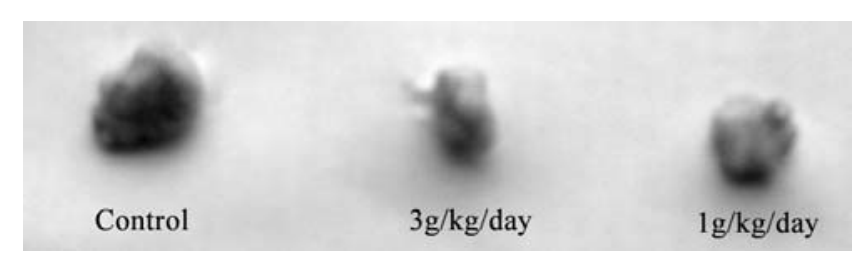

Figure 3. Anti-tumour effect of resveratrol on SPC-A-1/CDDP cells in nude mice: dose-dependent effects of resveratrol on tumour volume and tumor weight in nude mice injected with SPC-A-1/CDDP cells.

cells) both in vitro and in vivo. We found that resveratrol significantly inhibited SPS-A-1/CDDP cell proliferation at each concentration we tested, but the effect was most pronounced in cells treated with $100 \mu \mathrm{M}$ resveratrol at $96 \mathrm{~h}$ compared with free-control cells. In the following experiment, we found that resveratrol could also induce apoptosis and arrest the cell cycle at $\mathrm{G}_{0}-\mathrm{G}_{1}$ and could do so in a time- and dose-dependent manner, with the $100 \mu \mathrm{mo} / 1$ concentration having the largest effect on apoptosis and cell cycle distribution. Thus, resveratrol had dose- and time-dependent effects on the SPC-A-1/CDDP cell proliferation, apoptosis and cell cycle phase distribution. These findings suggest that high-dose resveratrol may be more effective than low-dose resveratrol in the treatment of drug-resistant human nonsmall cell lung cancer SPS-A-1/CDDP cells and that resveratrol may be a novel way to treat actual patients' tumours.

In the next set of experiments, we studied the effect of resveratrol on the $\mathrm{IC}_{50}$ of the anti-tumour drugs cisplatin, gefitinib and paclitaxel. Results showed that the treatment of SPS-A-1/CDDP cells with resveratrol significantly decreased the $\mathrm{IC}_{50}$ of each of the anti-tumour drugs we tested, suggesting that resveratrol increased the chemosensitivity SPC-A-1/ CDDP cells. Therefore, resveratrol may be a good adjuvant treatment for patients suffered from multidrug-resistant NSCLC. Additionally, resveratrol had a dose-dependent effect on the $\mathrm{IC}_{50}$ of the various chemotherapeutic drugs that were tested, with $100 \mu \mathrm{mol} / 1$ resveratrol causing the largest reduction in the $\mathrm{IC}_{50}$ values. In our in vivo studies, we observed that resveratrol had anti-tumour effects on nude mice that had been injected with SPC-A-1/CDDP cells. Resveratrol led to significantly lower tumour volumes in mice either that were fed either 1 or $3 \mathrm{~g} / \mathrm{kg} /$ day resveratrol as compared to untreated mice. The effect was especially marked in the mice treated with the highest dose of resveratrol, thus again demonstrating that resveratrol has a dose-dependent effect on tumours. These findings suggest that we should seek to identify the maximal safe dose of resveratrol both in vitro and in vivo.

We next examined survivin expression in resveratroltreated and control SPC-A-1/CDDP cells. Survivin is a member of the inhibitor of apoptosis protein (IAP) family that inhibits apoptosis and regulates cell division (32). Survivin has been implicated in both the control of cell division and the inhibition of apoptosis (33). Specifically, its anti-apoptotic function seems to be related to the ability to directly or indirectly inhibit caspases. Survivin is expressed in embryonic tissues as well as in the majority of human cancers, but is not expressed in most normal adult tissues and is associated with chemotherapy resistance (34), and patients with survivin-expressing 
tumours have poorer survival (35). Studies have found that patients with tumours that do not express survivin or only express it in low levels have more favourable outcomes. Conversely, high survivin expression was found to be correlated with unfavourable outcomes (36). The cancerspecific expression of survivin in adults, coupled with its importance in inhibiting cell death and in regulating cell division, makes it a useful diagnostic marker for human cancers as well as a potential target for cancer treatment. Based on these findings, survivin has been proposed as an attractive target for new anticancer interventions $(37,38)$. In our last experiment, we found that the expression of survivin in SPCA-1/CDDP cells decreased after treatment with resveratrol (at any concentration). Resveratrol was found to decrease survivin levels in a time- and dose-dependent manner. We also examined another pathway involved in apoptosis, the caspase cascade, which cleaves key cellular components, including cytoskeletal proteins and nuclear proteins, and leads to an altered cellular morphology, which we observed in resveratrol-treated SPC-A-1/CDDP cells.

Our study showed that caspase-3 was activated immediately after exposure to resveratrol. However, inhibition of survivin expression and initiation of the caspase cascade occurred at almost the same time, so the caspase cascade may in fact be activated by the inhibition of survivin. We have not excluded a caspase-independent mechanism for resveratrol-induced apoptosis. However, we do think that both the survivinmediated intrinsic pathway, as well as the caspase-3-mediated extrinsic pathway, play an important role in resveratrolinduced apoptosis. Although there is a lot of work yet to be done to study the mechanism by which resveratrol exerts an effect on survivin, survivin may be a novel target for chemotherapeutic drugs and resveratrol may play an important role in the treatment of multidrug-resistant human NSCLC.

In conclusion, resveratrol exerted dose- and/or timedependent effects on the inhibition of SPC-A-1/CDDP cell proliferation and the induction of apoptosis in these cells. It also arrested the cell cycle at phase $\mathrm{G}_{0}-\mathrm{G}_{1}$, decreased the $\mathrm{IC}_{50}$ values of different anti-tumour drugs, and decreased survivin expression in mice injected with SPC-A-1/CDDP cells (thereby exerting an anti-tumour effect) in a dose- and timedependent manner.

\section{Acknowledgements}

The authors would like to thank Nan You and Rui Ma for their excellent technical assistance and Hong Lin for his helpful input.

\section{References}

1. Mahaffey CM, Zhang H, Rinna A, Holland W, Mack PC and Forman HJ: Multidrug-resistant protein-3 gene regulation by the transcription factor Nrf2 in human bronchial epithelial and nonsmall-cell lung carcinoma. Free Radic Biol Med 46: 1650-1657, 2009.

2. Luster TA, Carrell JA, McCormick K, Sun D and Humphreys R: Mapatumumab and lexatumumab induce apoptosis in TRAILR1 and TRAIL-R2 antibody-resistant NSCLC cell lines when treated in combination with bortezomib. Mol Cancer Ther 8: 292-302, 2009.
3. Tooker P, Yen WC, Ng SC, Negro-Vilar A and Hermann TW: Bexarotene (LGD1069, Targretin), a selective retinoid X receptor agonist, prevents and reverses gemcitabine resistance in NSCLC cells by modulating gene amplification. Cancer Res 67: 4425-4433, 2009

4. Lee ES, Gao Z, Kim D, Park K, Kwon IC and Bae YH: Super $\mathrm{pH}$-sensitive multifunctional polymeric micelle for tumor $\mathrm{pH}(\mathrm{e})$ specific TAT exposure and multidrug resistance. J Control Release 129: 228-236, 2008.

5. Oguri T, Ozasa H, Uemura T, Bessho Y, Miyazaki M, Maeno K, Maeda $\mathrm{H}$, Sato $\mathrm{S}$ and Ueda R: MRP7/ABCC10 expression is a predictive biomarker for the resistance to paclitaxel in nonsmall cell lung cancer. Mol Cancer Ther 7: 1150-1155, 2008.

6. Kuang Y, Rogers A, Yeap BY, Wang L, Makrigiorgos M, Vetrand K, Thiede S, Distel RJ and Janne PA: Noninvasive detection of EGFR T790M in gefitinib or erlotinib resistant nonsmall cell lung cancer. Clin Cancer Res 15: 2630-2636, 2009.

7. Garofalo M, Quintavalle C, Di Leva G, Zanca C, Romano G, Taccioli C, Liu CG, Croce CM and Condorelli G: MicroRNA signatures of TRAIL resistance in human non-small cell lung cancer. Oncogene 27: 3845-3855, 2008

8. Kosaka T, Yatabe Y, Endoh H, Yoshida K, Hida T, Tsuboi M, Tada H, Kuwano $\mathrm{H}$ and Mitsudomi T: Analysis of epidermal growth factor receptor gene mutation in patients with non-small cell lung cancer and acquired resistance to gefitinib. Clin Cancer Res 12: 5764-5769, 2006.

9. Aiba I, Hossain A and Kuo MT: Elevated GSH level increases cadmium resistance through down-regulation of $\mathrm{Sp} 1$-dependent expression of the cadmium transporter ZIP8. Mol Pharmacol 74: 823-833, 2008.

10. Hain R, Reif HJ, Krause E, et al: Disease resistance results from foreign phytoalexin expression in a novel plant. Nature 361: 153-156, 1993.

11. Lee KW, Kang NJ, Heo YS, et al: Raf and MEK protein kinases are direct molecular targets for the chemopreventive effect of quercetin, a major flavonol in red wine. Cancer Res 68: 946-955, 2008 .

12. Kaeberlein M and Rabinovitch PS: Medicine: grapes versus gluttony. Nature 444: 280-281, 2006.

13. van Ginkel PR, Sareen D, Subramanian L, Walker Q, Darjatmoko SR, Lindstrom MJ, Kulkarni A, Albert DM and Polans AS: Resveratrol inhibits tumor growth of human neuroblastoma and mediates apoptosis by directly targeting mitochondria. Clin Cancer Res 13: 5162-5169, 2007.

14. Baur JA, Pearson KJ, Price NL, et al: Resveratrol improves health and survival of mice on a high-calorie diet. Nature 444: 337-342, 2006.

15. Joe AK, Liu H, Suzui M, Vural ME, Xiao D and Weinstein IB: Resveratrol induces growth inhibition, S-phase arrest, apoptosis, and changes in biomarker expression in several human cancer cell lines. Clin Cancer Res 8: 893-903, 2008.

16. Ahmad KA, Harris NH, Johnson AD, Lindvall HC, Wang G and Ahmed K: Protein kinase CK2 modulates apoptosis induced by resveratrol and epigallocatechin-3-gallate in prostate cancer cells. Mol Cancer Ther 6: 1006-1012, 2007.

17. Mitchell SH, Zhu W and Young CY: Resveratrol inhibits the expression and function of the androgen receptor in $\mathrm{LNCaP}$ prostate cancer cells. Cancer Res 59: 5892-5589, 1999.

18. Holmes-McNary M and Baldwin AS: Chemopreventive properties of trans-resveratrol are associated with inhibition of activation of the IkappaB kinase. Cancer Res 60: 3477-3483, 2000.

19. Opipari AW Jr, Tan L, Boitano AE, Sorenson DR, Aurora A and Liu JR: Resveratrol-induced autophagocytosis in ovarian cancer cells. Cancer Res 64: 696-703, 2004.

20. Hsieh TC, Juan G, Darzynkiewicz Z and Wu JM: Resveratrol increases nitric oxide synthase, induces accumulation of p53 and p21(WAF1/CIP1), and suppresses cultured bovine pulmonary artery endothelial cell proliferation by perturbing progression through S and G2. Cancer Res 59: 2596-2601, 1999.

21. Pignon JP, Tribodet H, Scagliotti GV, et al: Lung adjuvant cisplatin evaluation: a pooled analysis by the LACE Collaborative Group. J Clin Oncol 26: 3552-3559, 2008.

22. Gridelli C, Maione P, Illiano A, et al: Cisplatin plus gemcitabine or vinorelbine for elderly patients with advanced non-small-cell lung cancer: the MILES-2P studies. J Clin Oncol 25: 4663-4669, 2007.

23. Judde JG, Rebucci M, Vogt N, et al: Gefitinib and chemotherapy combination studies in five novel human non-small cell lung cancer xenografts. Evidence linking EGFR signaling to gefitinib antitumor response. Int J Cancer 120: 1579-1590, 2007. 
24. Hsu DS, Balakumaran BS, Acharya CR, et al: Pharmacogenomic strategies provide a rational approach to the treatment of cisplatin-resistant patients with advanced cancer. J Clin Oncol 25: 4350-4357, 2007.

25. Joshi KS, Rathos MJ, Mahajan P, et al: P276-00, a novel cyclindependent inhibitor induces G1-G2 arrest, shows antitumor activity on cisplatin-resistant cells and significant in vivo efficacy in tumor models. Mol Cancer Ther 6: 926-934, 2007.

26. Girnun GD, Chen L, Silvaggi J, et al: Regression of drugresistant lung cancer by the combination of rosiglitazone and carboplatin. Clin Cancer Res 14: 6478-6486, 2008.

27. Yen WC, Corpuz MR, Prudente RY, Cooke TA, Bissonnette RP, Negro-Vilar A and Lamph WW: A selective retinoid X receptor agonist bexarotene (Targretin) prevents and overcomes acquired paclitaxel (Taxol) resistance in human non-small cell lung cancer. Clin Cancer Res 10: 8656-8664, 2004.

28. Engelman JA and Janne PA: Mechanisms of acquired resistance to epidermal growth factor receptor tyrosine kinase inhibitors in non-small cell lung cancer. Clin Cancer Res 14: 2895-2899, 2008.

29. Costa DB, Nguyen KS, Cho BC, et al: Effects of erlotinib in EGFR mutated non-small cell lung cancers with resistance to gefitinib. Clin Cancer Res 14: 7060-7067, 2008

30. Blumenstein I, Keseru B, Wolter F and Stein J: The chemopreventive agent resveratrol stimulates cyclic AMP-dependent chloride secretion in vitro. Clin Cancer Res 11: 5651-5656, 2005.

31. Jazirehi AR and Bonavida B: Resveratrol modifies the expression of apoptotic regulatory proteins and sensitizes nonHodgkin's lymphoma and multiple myeloma cell lines to paclitaxel-induced apoptosis. Mol Cancer Ther 3: 71-84, 2004.
32. Li F, Ambrosini G, Chu EY, Plescia J, Tognin S, Marchisio PC and Altieri DC: Control of apoptosis and mitotic spindle checkpoint by survivin. Nature 396: 580-584, 1998.

33. Alvaro T, Lejeune M, Garcia JF, Salvado MT, Lopez C, Bosch R, Jaen J, Escriva P and Pons LE: Tumor-infiltrated immune response correlates with alterations in the apoptotic and cell cycle pathways in Hodgkin and Reed-Sternberg cells. Clin Cancer Res 14: 685-691, 2008.

34. You RI, Chen MC, Wang HW, Chou YC, Lin CH and Hsieh SL: Inhibition of lymphotoxin-beta receptor-mediated cell death by survivin-DeltaEx3. Cancer Res 66: 3051-3061, 2006.

35. Chakravarti A, Noll E, Black PM, Finkelstein DF, Finkelstein DM, Dyson NJ and Loeffler JS: Quantitatively determined survivin expression levels are of prognostic value in human gliomas. J Clin Oncol 20: 1063-1068, 2002.

36. Schlette EJ, Medeiros LJ, Goy A, Lai R and Rassidakis GZ: Survivin expression predicts poorer prognosis in anaplastic large-cell lymphoma. J Clin Oncol 22: 1682-1688, 2004.

37. Mita AC, Mita MM, Nawrocki ST and Giles FJ: Survivin: key regulator of mitosis and apoptosis and novel target for cancer therapeutics. Clin Cancer Res 14: 5000-5005, 2008.

38. Blanc-Brude OP, Mesri M, Wall NR, et al: Therapeutic targeting of the survivin pathway in cancer: initiation of mitochondrial apoptosis and suppression of tumor-associated angiogenesis. Clin Cancer Res 9: 2683-2692, 2003. 